\title{
Early Childhood Education Based on Family
}

\author{
Anayanti Rahmawati, Ruli Hafidah, Muhammad Munif Syamsuddin
}

Faculty of Teacher Training and Education, Universitas Sebelas Maret, Surakarta, Indonesia

Corresponding e-mail: anayanti.rahmawati@yahoo.co.id

\begin{abstract}
The parents are the most responsible agent to their children education. Currently these responsibilities tend to be delegated to schools and teachers. The parents should be good partner with school, because education are implemented in schools should be run linearly with education in the family. This study describes the various activities that involve parents in their child's education. It is called early childhood Education based on family, namely early childhood that took the family to actively participate in children learning activities in school. This study applied scientific literature study method. Some literatures used as sources in this study, among them covering handbook, research journals review, books reference, and Indonesian republic government policies (laws and regulations). The results show that there are many ways to do so that parents and families have an involvement in childrens education, among others through joint activities in the school such as outing class, cooking class, parent class as well as expert assistance and the others, so the parents know the child's learning activities conducted in schools and can provide a similar stimulation at home.
\end{abstract}

Keywords: early childhood education, parenting, family

\section{INTRODUCTION}

Children's education should start as early as possible, even from the children yet to be born (Abdurrahman, 2005). The beginning of a child's education should be started simultaneously with the inauguration of a legitimate marriage bond as husband and wife, through the planning of educational concepts that will be applied later to their children based on religious teachings. Furthermore, these concepts continue when the child in the mother's womb, because actually since that a child was able to hear and feel the affection and parental expectations. But the real children's education significantly starting since the child is born.

Child is a gift from God that entrusted to parents and whose presence is always welcomed with pleasure and pride (Hasan, 2012) so that parents are obliged to care for, nurture and guide children as well as possible. Therefore, it is not wrong if it is then said to be the responsibility of the education of children in the hands of parents fully. However, responsibility for children's education is not necessarily really fully be done alone by parents, but parents can cooperate with other parties in order to provide the best education for children.

At the present time, it has developed a variety of institutions of Early Childhood Education (ECE), which can be used as a partner for parents in helping implementation educations for children. Today, there are various school early childhood institutions with a range of services available include child care, pre-schools and kindergartens. parents' animo against the existence of these institutions is quite high, as evidenced by many parents that enter their children to get services in these institutions.

But in reality, often after children join in the early childhood care institutions, parents become complacent with their role as the primary educator's children. Many parents who seemed likely to wash their hands of the responsibility for children's education by transferring these responsibilities entirely on teachers and early childhood institutions. Many parents believe that teachers are more experienced and competent to educate children so they tend to be full surrender on the child's education to teacher. In addition, parents often assume that 
because they have paid for children's education, they no longer need to think about children's education.

This assumption is not correct, because school and teacher is only one tool in the effort to provide education for children, but the responsibility of children's education is still remaining at parents. The reliance school as a place to educate children is not appropriate because most of the children's time is not spent all in school but together with their family and parents.

Even though activities carried children in school despite in the hours that children could learned effectively, but still less could touched private activity area private and intimacy. Meanwhile, activities carried out in the house most of the times when children need a lot of personal attention, intimacy and togetherness so that the role of the family, especially the parents as the primary children's educator are still not replaceable. Therefore, it is not wrong if Bronfrenbrenner (Papalia, 2008) says that development occurs through the growing process of interaction between individuals and environment, especially the family. If parents only rely on school in children's education so children's achievement could be less than optimal.

Given that majority parents still have a preconceived notion like this, this article will examine the importance of early childhood education based on family.

\section{METHOD}

This study applied scientific literature study method. Some literatures used as sources in this study, among them covering 1) Handbook, 2) research journals review, and 3) reference books 4) Indonesian republic government policies (laws and regulations). Literatures were searched manually by visiting some libraries as well as visiting places that are sources of information and also searching online using parenting, early childhood education and school as key words. Data analysis method used in this study is comparison analysis between theory.

\section{RESULT}

\subsection{Childhood Education Based on Family Definition}

Law No.20 of 2003 about National Education System stated that Early Childhood Education is a development effort aimed at children from birth up to the age of six years that is done through the provision of educational stimuli in order to help the growth and development of physical and spiritual so that children have readiness to enter next education. In the Indonesian Government Regulation No. 17 of 2010 mentioned that early childhood education serves to foster, cultivate and develop the full potential of early childhood optimally forming behavior and capabilities in accordance with the basic stages of development in order to prepared to enter further education. While the purpose of early childhood education is (1) establishing the foundation for the development of students' potentials to become a man of faith and piety to God Almighty, noble, healthy, knowledgeable, skilled, critical, creative, innovative, independent, selfconfident and become citizens of a democratic and responsible and (2) develop the potential of spiritual intelligence, intellectual, emotional, and social kinaesthetic learners at its golden period of growth in the environment play an educative and enjoyable.

In Law No. 23 of 2002 on the protection of children mentioned that the family is the smallest unit in a society consisting of a husband and wife or a husband and wife and son, or a father and son or mother and child or family of flesh in a straight line up or down until the third degree.

Children's education is the full responsibility of parents. When children are not yet in school, parents holding full authority children's education, but when children have had gone to school, parents have the partner in educating children so that the children's education authorities are no longer entirely in the hands of parents but has effect school's environment. However, the children's education responsibility is still remaining on parents so that it necessary to cooperate between parents and schools as patner.in order to strengthen this cooperation, so it is needed early childhood education based on family.

Early childhood education based on family is an early childhood learning cooperating in the implementation of the family as a partner. The family's role as a learning partner means that every study conducted in schools should be known and approved by family and family was expected to be involved in implementation of learning. The family's objectives involvement meant that families get to experience learning that is done at school so parents could have stimulated learning repetition at home. In addition, families could have controlled school's learning that is done at school so that when there is a discrepancy between family's learning 
concept with school's learning concept, it could be discussed for agreement.

Ministry of National Education (2011) explains that early childhood education based on family is an effort that aimed to early childhood that is conducted by family that is utilizing resources available in family's environment. Parents are expected to utilize resources in family's environment that is often overlooked. Optimizing the utilization of these families can partner with early childhood education.

From all explanation above, it can be concluded that early childhood education based on family is an early childhood education's learning that is making family as partner to collaborate in order to reach children's learning optimal.

\subsection{Early Childhood Education Based on Family's Learning}

Learning in early childhood based on family according to The Department of Education (2007) using the following principles:

1. Oriented in children's development. In doing so, educators need to provide activities in accordance with the stages of child development. Child is a unique individual, it is necessary to pay attention to individual differences. Thus, prepared activities need to consider how children's learning that starts from simple to complicated way, concrete to abstract, verbal to movement and egoistic to social sense.

2. Oriented to the needs of children. The learning activities in children should always be oriented on children needed. Early childhood is children who are in need of educational efforts to achieve optimization all aspects development (physical and psychological development that is intellectual, language, motor, social and emotional).

3. Playing and learning or learning while playing. Playing is a way for an early childhood learning. Through playing children explore to get to know the neighbourhood, find, utilize objects that close to the child and conclusions about the objects around. When playing, children develop an understanding with regard to his experience.

4. A conducive environment. The environment must be created in such a way so interesting and fun to pay attention to safety and comfort that can support children's play activities.

5. Cantered on children. Learning in early childhood should place child as a subject education. Therefore, all activities directed learning or child-cantered. In a child-cantered learning, children are given opportunity to make choices, express opinions and actively do or experience. Teachers act as mentors or facilitators.

6. Using an integrated learning. Learning in early childhood education using integrated learning. Wherein each of the learning activities include the development of all aspects of child development. This is done because of the developmental aspects with other aspects of development are interrelated. Integrated learning is done by using the theme as a vehicle to introduce various concepts to children in their entirety.

7. Develop a variety of life skills. The learning process is directed to develop a variety of life skills for children to help themselves, independent and responsible, self-disciplined and acquire useful skills for survival.

8. Using a variety of educational media and learning resources. Media and learning resources utilizes the surrounding environment, resource and materials deliberately prepared by educators.

9. Implemented gradually and repeatedly. Learning for young children should be carried out gradually, starting from a simple concept and close to the child. To achieve an optimal understanding of the concept of the delivery can be done repeatedly.

10. Active, creative, innovative, effective and fun. The process of active learning, creative, innovative, effective and fun can be done by children prepared by educators through exciting activities, fun to evoke a sense of cold out, motivating children to think critically and discover the new Hal. Learning management should be democratic, considering the child is the subject in the learning process.

11. The information technology. Implementation of stimulation in early childhood can use technology for smooth operation, egg tape, radio, television, computers. Utilization of information technology in the learning activities are intended to facilitate the child meet his curiosity.

Based on these explanations, it can be concluded that in early childhood learning must always be cantered on child and attention to comfort child. In general, learning principles have been used by teachers in the early childhood school, but comfort child is still often overlooked. Early childhood still has a high attachment and dependence with family, so that child will feel comfortable to be around family members, especially parents. A sense of 
comfort will make child relaxed that make it easier to absorb lesson that is being done.

In order to achieve learning's optimal outcomes, then school must strive to make situation as comfortable as possible for child by involve children's family in learning at school. Involving family in learning at school is a necessity, because teacher's task is actually just as parents' partner in educating children and children's education responsibility still remain on their parents. Rahman (2002) asserts that teacher's task is not to take over but continuing education in the family and help parents develop children's potential.

Therefore, we need early childhood education based on family. Ministry of National Education (2011) explains that early childhood education based on family is the education at early childhood that is conducted by family by utilizing resources available in family. This early childhood education based on family has a strong legal basis, because it is based on; (1) Constitution Republic of Indonesia No. 23 of 2002 on protection of children; (2) Constitution Republic of Indonesia No. 20 of 2003 on national education system; (3) Indonesian Government Regulation No. 17 of 2010 on management and delivery of education; (4) Regulation of the Minister of National Education Republic of Indonesia No. 58 of 2009 on early childhood education standards.

\subsection{Family's Role in Early Childhood Education}

Parents play an important role in children's education, because parents are the first and primary teacher for children. Through parents, child first learned everything around. Parents have final authority on matters that should or should not be done by children. Through daily interaction parents indirect educate their children. Early education instilled by parents will making basis children's understanding that is useful for next children's development. Various studies have shown the important role parental involvement in children's education, including Galindo \& Sheldon (2012) which states that family involvement in schools and parents' educational expectations have related to literacy and mathematics in early childhood education. Another study conducted by McWayne, Hampton, Fantuzzo, Cohen \& Sekino (2004) showed that parents who maintain a direct and regular contact with early childhood education will have children who showed positive engagement with peers, adults and learning.
Based on that research's it can be concluded that parental involvement in children's learning in early childhood education could not be ignored. Swick (2007) stated that quality home-school relationship positively related to children's skills in identifying letters and social competence. In addition, proximity and trust relationship between parent-teacher could foster child's school readiness skills. Therefore, it is important to encourage cooperation between families and schools. But the most important family's role is their support for programs that have been designed by early childhood education that involve parents. Without parents' support, programs that has been designed by early childhood education based on family will not be able to run optimally.

\subsection{Goals Early Childhood Education Based on Family}

The goals of early childhood education based on family is bring together the interests, hopes and wishes of early childhood education with the family. Early childhood education has a particular curriculum program that will be applied to child's learning, but its implementation cannot run optimally without family's support, especially parents. The existence of early childhood education based on family is expected to be a good link between early childhood education with family, especially parents.

Another goal that would be achieved in early childhood education based on family according to the Ministry of Education (2011) are (1) increasing awareness of parents or other family members as first educators and foremost; (2) improving knowledge, attitudes and skills of parents or other family members to make improvements to nutrition and health, care, upbringing, education and child protection; (3) improving role of parents or other family members in learning process of early childhood education that is hold by early childhood institutions and society; and (4) improving quality's implementation of early childhood education based on family.

In addition, early childhood education based on family has benefits include: (1) parents' involvement at school make parents know and understand children's activity and teachers in school; (2) parents could know the child's development stages in detail so that if there are deviations or constraints in child, parents may soon find an alternative solution immediately; (3) children's developmental could be more optimal because there is linear stimulation between school and family at home; (4) more 
intimate relationship between parent and child; (5) school program could work in harmony because of family's support.

\subsection{Implementation Early Childhood Education Based on Family}

Implementation early childhood education based on family could be done through a variety of activities that involve parents in school's learning. There are some principles to strengthen early childhood education based on family programs that empower family in early childhood school. Those principles include: (1) greater openness; (2) justice; (3) participatory; (4) cooperation and coordination; (5) integrated; (6) prioritizing excavation and development of local potential; (7) mobilization and awareness-raising; (8) implemented in phases; (9) continuous; (10) consistent; (11) commitment.

The form of activities in early childhood education based on family that can be done include:

1. The involvement of parents in school activities with the children which aims to bring relationship between parents, children, teachers and early childhood school. Activities that can be done include:

a. Parent class. In this class, parents go to children's class and learn as if they are children who are studying in class of early childhood education. This activity's purpose is to make parents feel and understand child's condition while learning in class and feel the learning undertaken by teachers. It is expected that by parent class, parents could better understand the learning process undertaken at school and could continue the learning at home.

b. Cooking class is cooking with the children in school, with the aim of strengthening parentchild relationship and their cooperation. This activity could be done in competition between pairs of parents and children at school.

c. Outing class is learning activities conducted outside classroom. The location selected class outing could be tailored to theme of learning that is being studied in classroom at the time.

d. Bazar day is activity of buying and selling that is done in a social purpose. This activity teaches children to have a social sensitivity and concern for social environment.

e. Gardening is an activity to plant and care for plants are maintained to be taken advantage.
Gardening can be started with planting of crops together at the school followed by plant maintenance. This activity could be continued at home respectively.

2. Seminar is a meeting organized to hear the opinions of experts on children's issues. These activities bring in experts in specific fields, such as doctors, psychologists, teachers or others and could also be public figures who have been successful in educating children. Seminar topics are based on the majority of issues that are happening in early childhood school. Through seminar, it is expected that parents could have better understand about child's development and making decisions for the child wisely.

3. Workshop, is a practical group activities to learn certain skills. Through workshop, parents would be guided to master certain skills. Expected skill mastery could be made economically so could help family's finances. Also, it could have made educationally so could help child's development. Workshop's theme that could be done alternatively include child's favourite food cooking, the use of junk around to make children's toys, educational games from recycled materials etc.

4. Community parenting family is a group of parents who meet regularly meeting in a certain time with the aim of discussing issues in children and seek alternative solutions. The existence of communities is important that parents could share with each other to optimize child's development. Members of this community is not only parents who have young children but can also public or other adults who have a high awareness in early childhood education.

5. Consultation with experts is a parents' activity with expert consultation on issues faced by children nor efforts to optimize child's potential. The consultation's objective is enable improvement of parents' ability to conduct early childhood education in the family. These consultations could continue towards mentoring experts to home visit if necessary.

6. Home visit is visiting family activities undertaken by manager or fellow parents of early childhood education to strengthening relationship, visit or help problem solving. Home visit may be accompanied by expert speakers for example psychologist, doctor or a person who is considered elderly in early childhood institutions. Should be avoided interrogation impression that the families who visit feel comfortable. 
7. Home activities that is an activity that could be done by parents along with other family members both inside and outside home, for example: picnic with family, eating with family, watching educational film.

\section{CONCLUSIONS}

Early childhood education based on family is an ideal early childhood education because the successful learning could not be realized without family's participation. The parents should be involved more than supporting infrastructure at school, but many activities in children's learning at school. It is able to represent the responsible parents in their children's education, so that education occurs in children not only from the school or the teachers. Early childhood educations are expected to hold parents closer again to be involved in children's activities at school. Parents' Psychological conditions that always wanted to be standby with their children and Parents' feeling proud of their children could be optimally given attention wisely by more involve parents in school's activities. It is hoped such efforts could be more accelerate the establishment of early childhood education based on family.

\section{REFERENCES}

Abdurrahman, J. (2005). Parenting Rasulullah (edisi terjemahan). Yogyakarta: Pustaka Rama.

Departemen Pendidikan Nasional. (2007). Kerangka Dasar Kurikulum Pendidikan Anak Usia Dini. Jakarta

Galindo, C. \& Seldon, S. B. (2012). School and Home Connections and Children's Kindergatren Achievement Gains: The Mediating Role Of Family Involvement. Early Childhood Research Quarterly 27, 90-103.

Hasan, T. (2012). Pendidikan Anak Usia Dini dalam Keluarga. Jakarta: Mitra Abadi Press.

Kamus Besar Bahasa Indonesia. (1995). Jakarta: Balai Pustaka.

Kementrian Pendidikan Nasional. (2011). Pedoman Penyelenggaraan Pendidikan Anak Usia Dini Berbasis Keluarga. Jakarta: Direktorat Pembinaan Pendidikan Anak Usia Dini. Direktorat Jenderal Pendidikan Anak Usia Dini, Nonformal Dan Informal.

McWayne, C., Hampton, V., Fantuzzo, J., Cohen, H. L., \& Sekino, Y. (2004). A multivariate examination of parent involvement and the social and academic competencies of urban kindergarten children. Psychology in the Schools, 41(3), 363-377.

Papalia, D.E., Old, S.W., Feldman, R.D. (2008). Psikologi Perkembangan (edisi terjemahan). Jakarta: Kencana Prenada Media Group.

Peraturan Pemerintah Republik Indonesia No. 17 tahun 2010 tentang Pengelolaan dan Penyelenggaraan Pendidikan.

Peraturan Menteri Pendidikan Nasional Republik Indonesia No. 58 tahun 2009 tentang Standar Pendidikan Anak Usia Dini.

Rahman, H.S. (2002). Konsep Dasar Pendidikan Anak Usia Dini. Jakarta: Penerbit EDSA Mahkota

Swick, D.C. (2007). The Effects of Parental Involvement On Children's School Readiness Skills. Desertation. University of North Carolina

Undang-Undang Republik Indonesia No. 23 tahun 2002 tentang Perlindungan Anak.

Undang-Undang Republik Indonesia No. 20 tahun 2003 tentang Sistem Pendidikan Nasional 